\title{
低温貯蔵野菜の品質および成分の変化 \\ The Changes of Quality and Composition of the Vegetables Stored at Cold Temperature
}

\author{
特に細胞組織，水分量およびアミノ態窒素含有量について
}

東京農業大学栄養学科食品原料学教室 (Dept. of Nutrition, Tokyo University of Agriculture)

高 間 総 子 (Fusako Takama) 斎 藤進 (Susumu Saito)

The investigation was planned to obtain the basal knowledge about the changes of quality and nutritional value of vegetables during transportation in the cold chain system.

Our previous report showed that the quality and the nutritional value of several vegetables stored at cold temperature were better than that stored at room temperature.

In the present paper, the microscopic observation was done for the tissue preparations of sweet pepper, tomato, and carrot stored under the same experimental conditions as previous report. And also moisture content and amino nitrogen content of the same samples were determined.

The results indicate that the greater changes of quality, in terms of hardness and of microscopic tissue conditions, in the samples stored at room temperature were observed than that of the samples stored at cold temperature. And there were significant decrease in moisture content and significant increase in amino nitrogen content in the samples stored at room temperature.

\section{緒言}

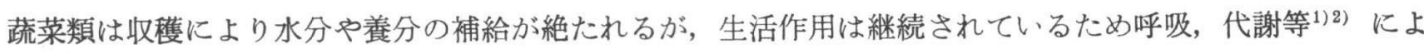
って蔬菜成分が消耗され品質低下を招く一原因となっている。

特に蔬菜中の水分は蒸散作用により減少し, 萎稠・目減りを起こし³), 歯ざわりや新鮮度の低下の原因, か つ取引上の損失ともなる。また水分蒸散の結果, 表皮細胞が変化し食品組織学的見地からも好ましくない。

われわれはこれまでに常温拉よび低温貯蔵蔬菜の品質と栄着価について報告し, 常温貯蔵・輸送は代謝成分 の変化が速かで品質の低下を認めたが低温輸送の蔬菜は遊離アミノ酸・不揮発酸等代謝成分の変化もほとんど 認められなかった。

生産地より温度条件を変えて東京へ輸送された, コールド・チェーン野菜の市販トマト, ピーマン, 人参,

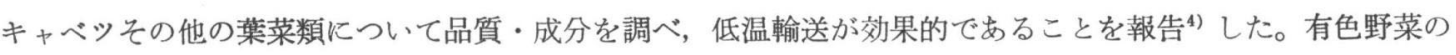
ブロッコリ，いんげんのクロロフィル含有量を比較した結果でも低温でよい効果のあったことを本訫に報告ら した。

そこで今回は特にピーマン,トマト, 招よび人参について前回試験と同種のものを用い品質と細胞組織, 水 分扰よびアミ，態窒素との関係についての実験をこころみたのでその結果を報告する。

\section{1. 実験材料および方法}

\section{1. 実験材料}

実験に供試した蔬菜類の生産地, 品種名招上び購入日は Table 1 のと招りである。 
Table 1 Producing district and variety of samples*

\begin{tabular}{lcl} 
& $\begin{array}{l}\text { Producing } \\
\text { District }\end{array}$ & Variety \\
\hline Sweet pepper & Kochi & California \\
Tomato & Tochigi & Fukuju \\
Carrot & Chiba & Gosun
\end{tabular}

* bought on Sep. 6, 1968
2. 実験方法

実験は下記の方法によって行なった。

(1) 貯蔵方法

Table 1 の蔬菜類を二分し, 室内貯蔵したものを室内区, ショーケース貯蔵を行なったものを低温貯蔵区とした。

(2) 貯蔵中の温湿度の測定

貯蔵中の温湿度はサーミスタ注射針型温度計で測定し，

6 打点自動記録温度計に接続した。

(3) 品質官能判別

新鮮度, 萎稠, 損㑑の有無, 色沢, 香味, 歯ざわりについて, 試料入手日および供試日に官能審查を行なっ た。

（4）水分括よび重量減少の測定

常法ど扰り貯藏全量に対し重量変化を調べ，また $105^{\circ} \mathrm{C}$ 乾燥法によって水分の測定を行なった。

(5) 生体の物理的測定および組織の検鏡

硬度：ユニバーサルハードネスメーター（5 kg）を用いた。各々について 5 カ体を供試し，トマトは果肉の 赤道部, 人参は根部のほほ真中の部分に各々 5 カ所にハードネスメーターの尖端をさし, ピーマンは果頂部 2 カ所にさした。

組織：検鏡用試料の調製は常法 ${ }^{6)}$ に従い, ピーマン拉よびトマトは果頂部より, 人参は肩部よりハンドセク ションにより切片をつくった。これを200倍と600倍で検鏡した。

（6）アミノ態窒素の定量

試料の圧搾㩁汁液を用い, ミクロヴァンスライ ク装置で定量を行なった。

\section{2. 実 験 結 果}

1. 環境温湿度

貯蔵試験期間中の室内拉よびショーケース内 の温湿度は Fig. 1 のと拈りで女る。

2. 品質官能判別

貯蔵中に扮ける蔬菜類の品質の変化は Table 2 の上うであり, ピーマンは室温貯蔵 6 日目に 颃いてかなり赤色に着色し 9 日目に至ってはほ とんど全体に赤く色着いたが，一方低温区の方 は新鮮さを保持していた。

トマトでは 3 日目に顷いて室温区は完熟して いるのに比べ，低温区ではかなり青味が残り， 温度条件による着色進行の速度の違いを明瞭に 示した。9日目では室温区は食用に適さない程

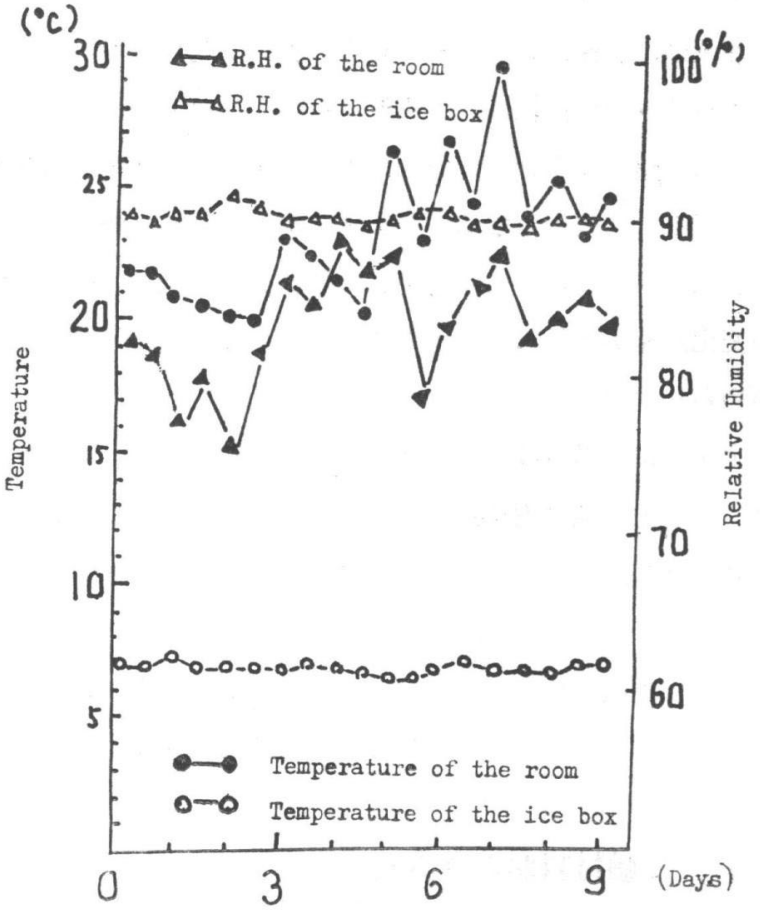

Fig. 1 Temperature and relative humidity of the environment during storage 


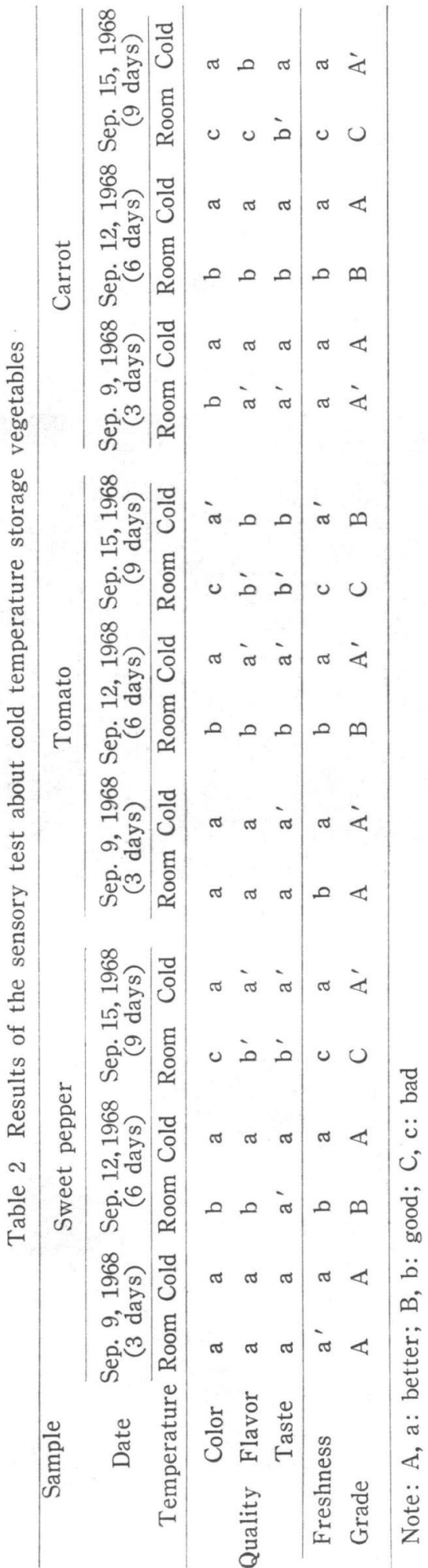

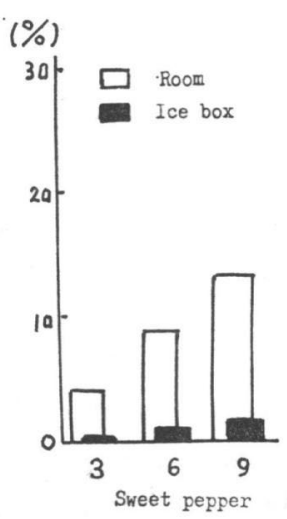
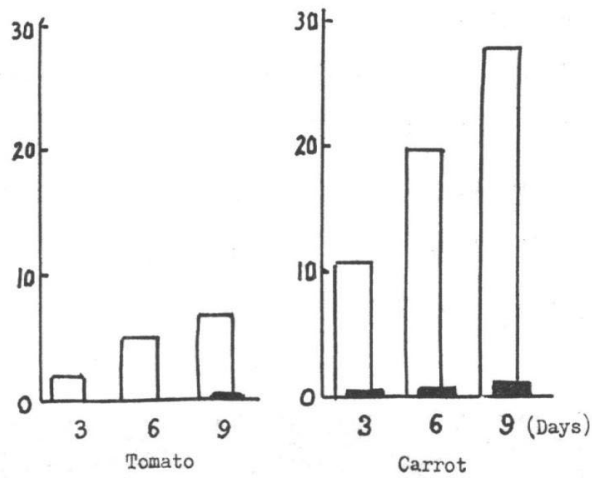

Fig. 2 Weight loss of vegetables during storage

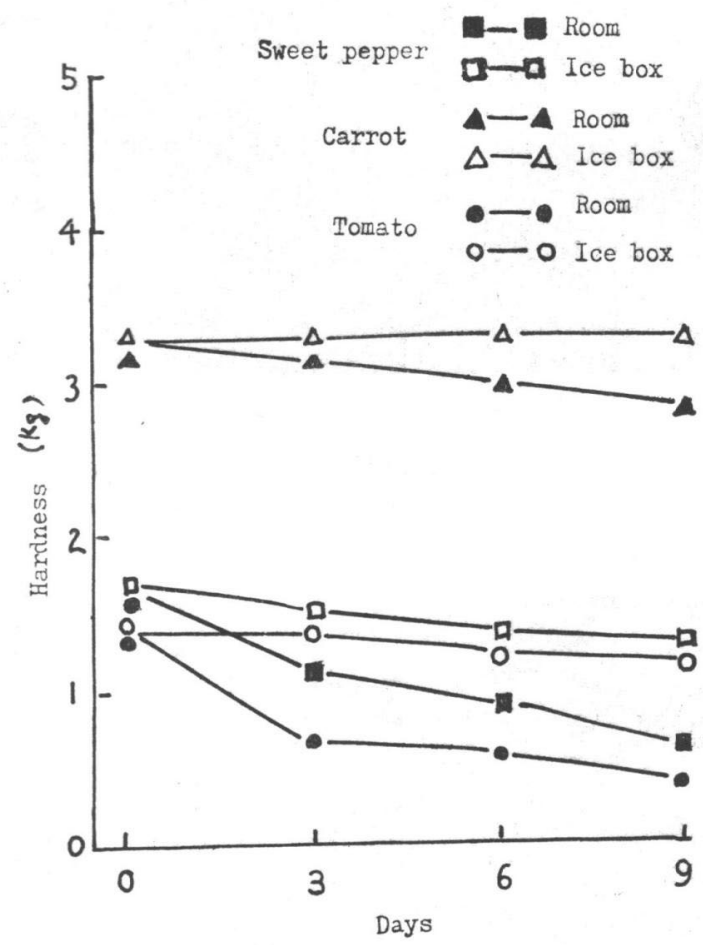

Fig. 3 Changes of hardness during storage

過熟しており，一方低温の方は青味が強い状態ではなはだしい品 質の差異をみせた。

一方人参では 3 日目に打いて室温の方にかなり表面の萎稠と褪 色をみせ，品質が低下していることを示した。9日目では低温区 はほとんど貯蔵当時と外観上変化がないのに室温の方は萎稠がはげしく，外観を著しくそこね, 極めて商品価 值が低下した。

3. 重量の減少 
貯蔵中の蔬菜類の重量の減少は Fig. 2 のような結果であった。室温区の方に著しい重量減少がみられた。 特に室温区人参において顕著であった。

4. 硬度の変化

貯蔵中の蔬菜の硬度は Fig. 3 のと括りである。いずれにおいても緩慢な減少をみせている。

5. 組織の変化

組織検鏡結果ではピーマンの 6 日目の表皮細胞は Photo 1 および 2 であり，室温区の方は低温区に比し， 細胞壁が肥厚していた。人参の 6 日目に拈ける表皮細胞の状態は Photo 3 および 4 のと打りであり, 室温の 方は低温より不鮮明な状態を示した。

Sections of epidermal tissue, room storage on left, cold storage on right.

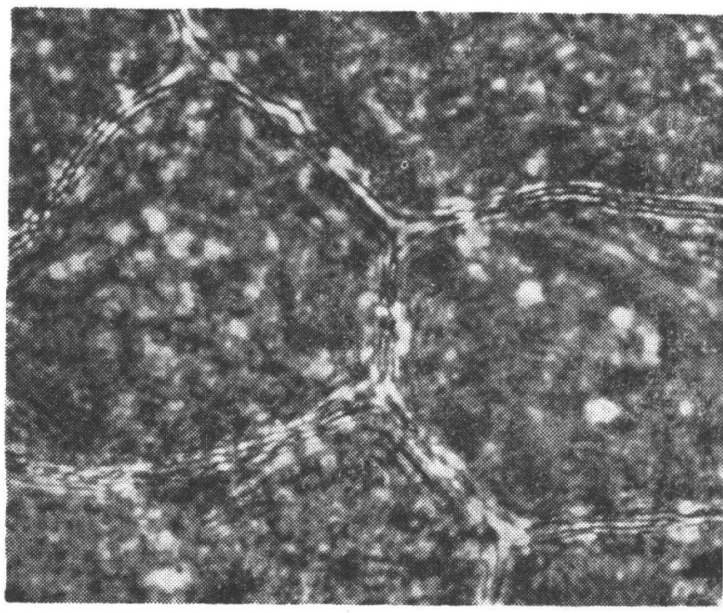

Photo 1 Room

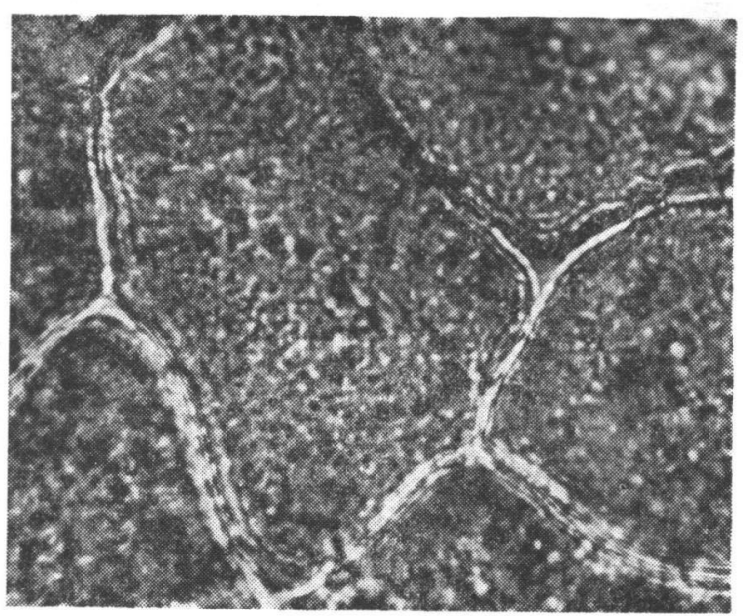

Photo 2 Ice box

Showing cell wall in sweet pepper (Storage for 6 days) magnification $\times 600$

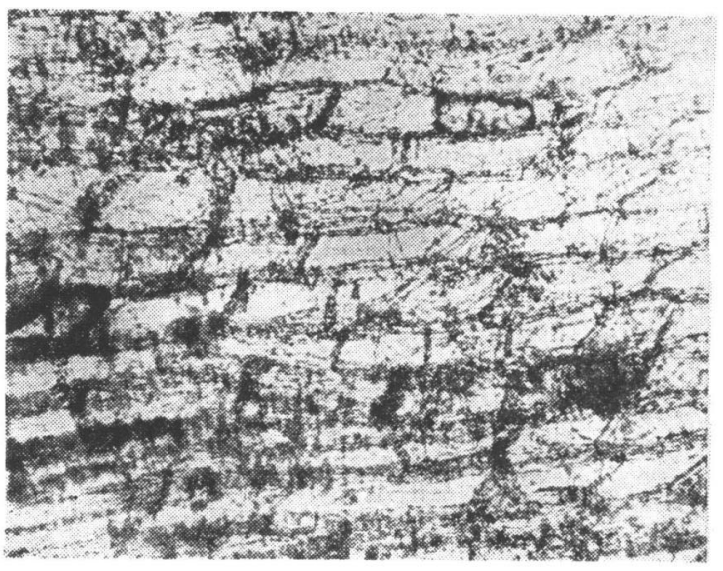

Photo 3 Room

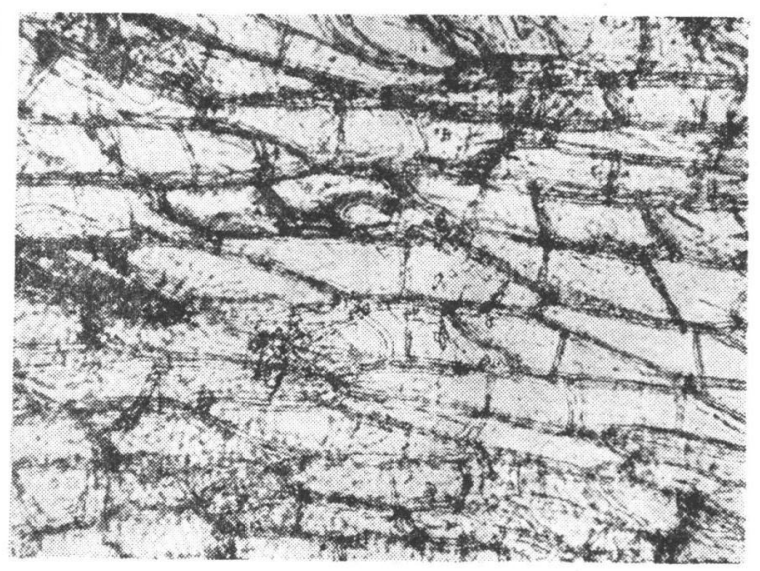

Photo 4 Ice box

Showing cell wall in carrot (Storage for 6 days) magnification $\times 200$

6. 水分量の変化

蔬菜貯蔵中の水分量を定量した結果は Fig. 4 のと扣りであった。 

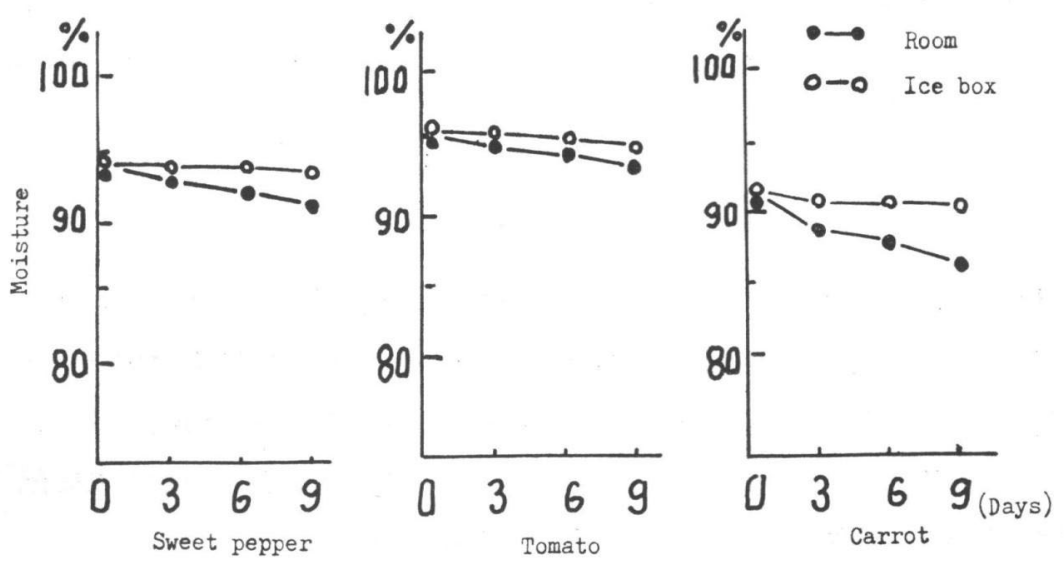

室温区は低温区に比べ水 分減少が速かであった。

7. アミノ態窒素含有 量の変化

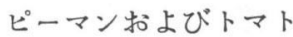
中のアミノ態窒素含有量 の定量結果は Fig. 5 抽 よび 6 のと拈りである。 室温区は低温区より增加 が著しい。両区間には,

Fig. 4 Changes of moisture in vegetables during storage

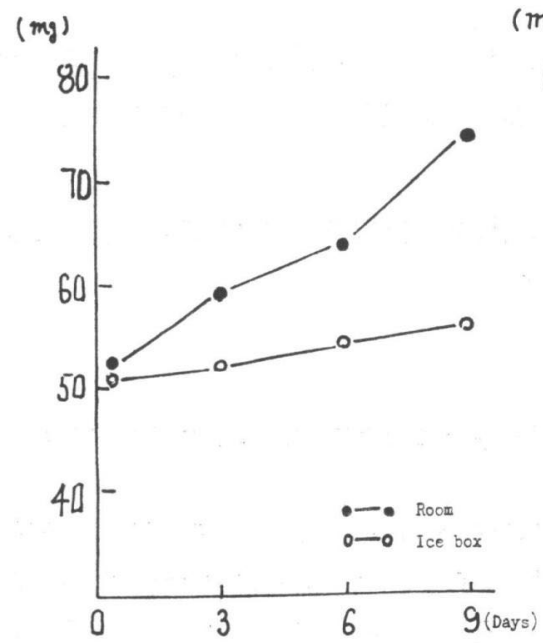

Fig. 5 Changes of amino nitrogen in tomato during storage

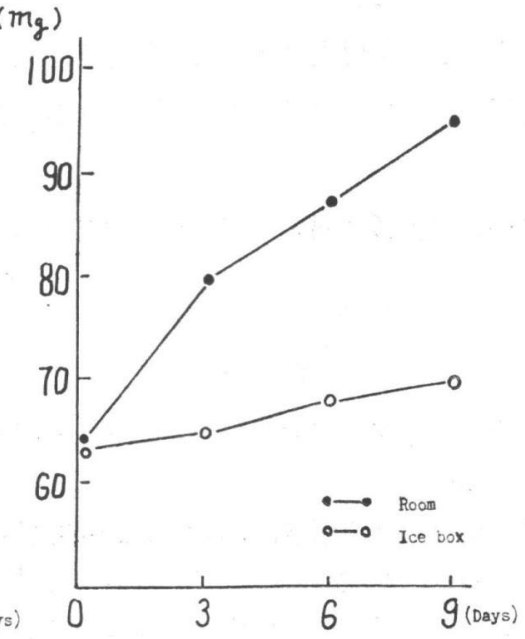

Fig. 6 Changes of amino nitrogen content in sweet pepper during storage
貯蔵によるアミノ態窒素 量の消長に変化がみられ た。

\section{3. 考 察}

以上を考察すれば次の ようである。

1）眝蔵中の環境温湿 度の測定結果では低温区 のものは常に温湿度は一 定に保たれ，急激な変化 はみられなかったが，常 温区では外気によりかな り急激な变化を示した。 そこで貯蔵期間中の環境

温湿度の変化の少ないことが植物生理上, 品質低下の防止に役立っているものと考觉られる。

2）貯蔵中の重量減少率は蔬菜の種類，貯蔵の環境条件によって違うが，何れも低温区のものは僅少であっ た。これは北尾7)がカンランについて行なった予冷試験，小畑 ${ }^{3)}$ が白菜について行なった低温貯蔵試験におい ても低温が重量減少防止に有効であることを報告している。をた重量減少の少ないことは青果物の経済価値に も関係ある重要なるのと考兄られる。

3）蔬菜の色沢・香味等の品質, 新鮮度は低温眝蔵のものは良好であったが，ただし低温により熟度が進ま なくなるトマトでは低温のるのは色づきが悪くこの点収穫時期の選択等今後検討の余地があると思われる。

4）硬度は蔬菜の種類によって違らが，3種の蔬菜では新鮮度が低下寸ると硬度も低くなり，組織軟化の指 標となり得るよ 5 に思われた。また生体組織の変化をみる予備試験としてその表皮細胞を検鏡したところ, 低 温のものと室温のものでは 3 種の蔬菜ともとの細胞膜に变化がみられた。組織の変化は味覚のうち物理的触感 にも影響を与えるものと考光られる。これは Meyer ${ }^{8)}$ も細胞膜は果実の熟期, 加工により変化するとしてい る。 
5）ピーマン, トマト貯蔵中のアミノ態窒素の経時変化をみたところ, 室温貯蔵のものは低温にくらべ著し く增加の傾向を示した。この增加量は生体中の水分含有量の消長を考慮してもかなり大きいことを認めた。小 畑は白菜で温度を変え貯蔵した場合，両区間にはアミノ態窒素の消長9があるとしている。

\section{要 約}

低温に括ける野菜貯蔵の効果をみるため, 試料にピーマン, トマト拈上び人参を用いて，対象区を室温とし 品質, 重量, 水分量, 硬度, 細胞組織执よびアミノ態窒素量の経時的変化をみた。その結果低温に貯蔵したも のは室温のものに比し重量の減少は少なく水分含有量も多く, 従って品質, 鮮度の低下が少なかった。しかし 硬度測定の結果では室温貯蔵のものは数值が低く軟化の早いことを示し, さらに組織の切片を検鏡した場合, この区のものは表皮細胞に変化がみられ, 鮮度, 品質の低下が明らかであった。な扎ピーマン, トマトのアミ ノ態窒素量の経時的変化では低温のものに比し室温貯蔵のものは含有量の増加が認められ, 内容成分の変化も 野菜貯蔵の温度条件で異なることを示した。

以上低温で蔬菜を貯蔵する場合低温は生鮮食品としての新鮮度，品質の保持によい影響を与えていることを 水分の含有量とこれに関する消耗率，組織の硬軟，細胞膜の状態掞よびアミノ態窒素の消長より確認すること ができた。

終りにのぞみ, 組織の実験について御援助賜った東京農業大学植物病理学研究室丹田誠之助氏に深甚なる謝 意を表する。

\section{参考文 献}

1) 本多靖, 石黒修 : 果実とそ菜の保存に関する研究，果実とそ菜の呼吸におよぼす環境ガス組成の影響， 園芸学雑誌, 36, 3, 363 (1967)

2 ) 岡本辰夫 : 青果物に拈ける C A 貯蔵の原理, 日本食品工業学会第15回大会シンポジウム講演集, 5(1968)

3 ) 小畑正行 : はくさいの低温輸送貯蔵試験について, 包装輸送試験成績書, 東京都農業試験場, 35(1967)

4) 斎藤進, 狩野総子 : 低温貯蔵と輸送の蔬菜果実の品質に関する研究 (第 3 報) 特に市販低温流通蔬菜の 品質, 栄養価について, 東京農業大学農学集報, 13, 2, 68 (1968)

5 ) 斎藤進, 高間総子, 田中なな子, 杉崎順子 : 有色野菜貯蔵中の生体色素の変化, 栄湌学雑誌, 28, 6, 233 (1970)

6 ) 小島正夫 : 植物形態学実験法, 広川書店, 139 (1965)

7 ) 北尾次郎 : カンランの予冷について, 農林省専門別総括検討会議資料 (利用加工), 昭和 42 年度版, 1 2 (1967)

8 ) Meyer, L. H.: Food Chemistry, Reinhold Publishing Corporation, New York, 264 (1961)

9) Bonner, J.: Plant Biochemistry, Academic Press Publishing Company, New York, 525 (1952)

10) 狩野総子, 紊藤進 : 低温貯蔵野菜の水分含有量と品質の変化, 栄養改善学会第15回大会講演要旨(1968)

（受付：昭和46年10月29日） 